\title{
The Role of Agricultural Extension in Apple crop Marketing in Paktia
}

\section{Province-Afghanistan}

\section{Sherpaw Ahmadi}

(M.Sc.) Assistant professor of agricultural economics and extension department of Shaikh Zayed University Khost, Afghanistan.

Email: sherpaw.ahmadi@gmail.com

\section{Heshmatollah Saadi}

(Ph. D) Associate professor of agricultural extension education department of Bu Ali Sena

University Hamedan, Iran

Email: $\underline{\text { Hsaadi48@ basu.ac.ir }}$

\section{Muhsenullah Irfan}

(M.Sc.) Assistant professor of agricultural economics and extension department of Paktia University, Afghanistan

Email: muhsen.irfan@gmail.com

\section{Raza Movahedi}

(Ph. D) Associate professor of agricultural extension education department of Bu Ali Sena University Hamedan, Iran

Email: movahedi686@yahoo.com

\begin{abstract}
:
The basic objective of this research assessing the role of agricultural extension in apple crop marketing and identify was better methods for problem resolution in Paktia province Afghanistan. This research according to the objective is applied research and the base of data collection methods is survey research and statistics population of this research were farmers which is many 200 farmers were selected as sample size. Used for this aim Cochran Formula. this research has questioners of 61 questions and assessment validity of questioner profits from agricultural extension department lecturer's an alpha Cronbach's Coefficient used by SPSS version 26 software are funded .and acceptable number.
\end{abstract}


The result of the research is showing the technology of industry-appropriate for product cultivation, protection, and harvesting. Extreme fluctuations, non-guaranteed agricultural product costs are the most important problems of the apple producers. In Paktia province. Analytical results show extension factors and awareness balance of apple producers to have direct and meaningful contact. Regression results show to visit with agents of change, use audiovisual media and Participation in educational classes are \%50 awareness level comprised. In the end, there was more growth and for the betterment condition of production and apple, crop marketing is a necessary attention to extension.

Keywords: Agricultural Extension, Marketing, apple producers ‘ Paktia province. Afghanistan/

\section{Introduction}

Agriculture has an important role in the economy of Afghanistan and we can say the agriculture is the backbone of Afghanistan economy .and 12 million people were busy in the agriculture sector and $21 \%$ allotment of agriculture in GDP and this country has a reasonable climate for the horticulture sector products and annually produce millions tone different of high-quality fruit.

After 2010 the agricultural products have translatable allocation in the international market. (Zanello, G et al 2019) Afghanistan's horticultural products are exported to the different countries' markets of the world (NSA, 2018) according to the world bank report agricultural development between the 2014 to 2016 years were created 2.25 million work opportunities (World Bank 2017). In Afghanistan, around 2.7\% of arable land in 2018 is cultured on fruits in different seasons of the year produced more fruits products exexported to regional and international markets. however, Afghanistan's current condition agriculture development process is faced with many problems., lack of access to international markets, farmer's illiteracy, agricultural products traditional methods, less use electrical energy. Insufficient budget for agricultural development projects, decrease technical manpower for agricultural activities and products exports problems, in the field of marketing no access to cool stores for storing, extreme fluctuations of costs, and unstandardized system of transportation, no accessibility to roads for agricultural products transit from farm to market, mistime products sale in internal markets or sale in foreign markets is another agricultural problems of Afghanistan. 
Afghanistan is an important apple producer country of the world and annually produces 217192 metric tons in 28381-hectare. (MAL 2020) graph 1 is showing at the end of last year apple products arise upward than the last two decades all cultivations were traditionally and by the initiative of agricultural extension now gradually toward modernization. And profitable apple product in Afghanistan before 25 years. Afghanistan has a delectable and sweets apple and until 7 months keeping the taste and pureness in cool stores.

\section{Graph 1 Afghanistan total apple production from 2010- 2017}

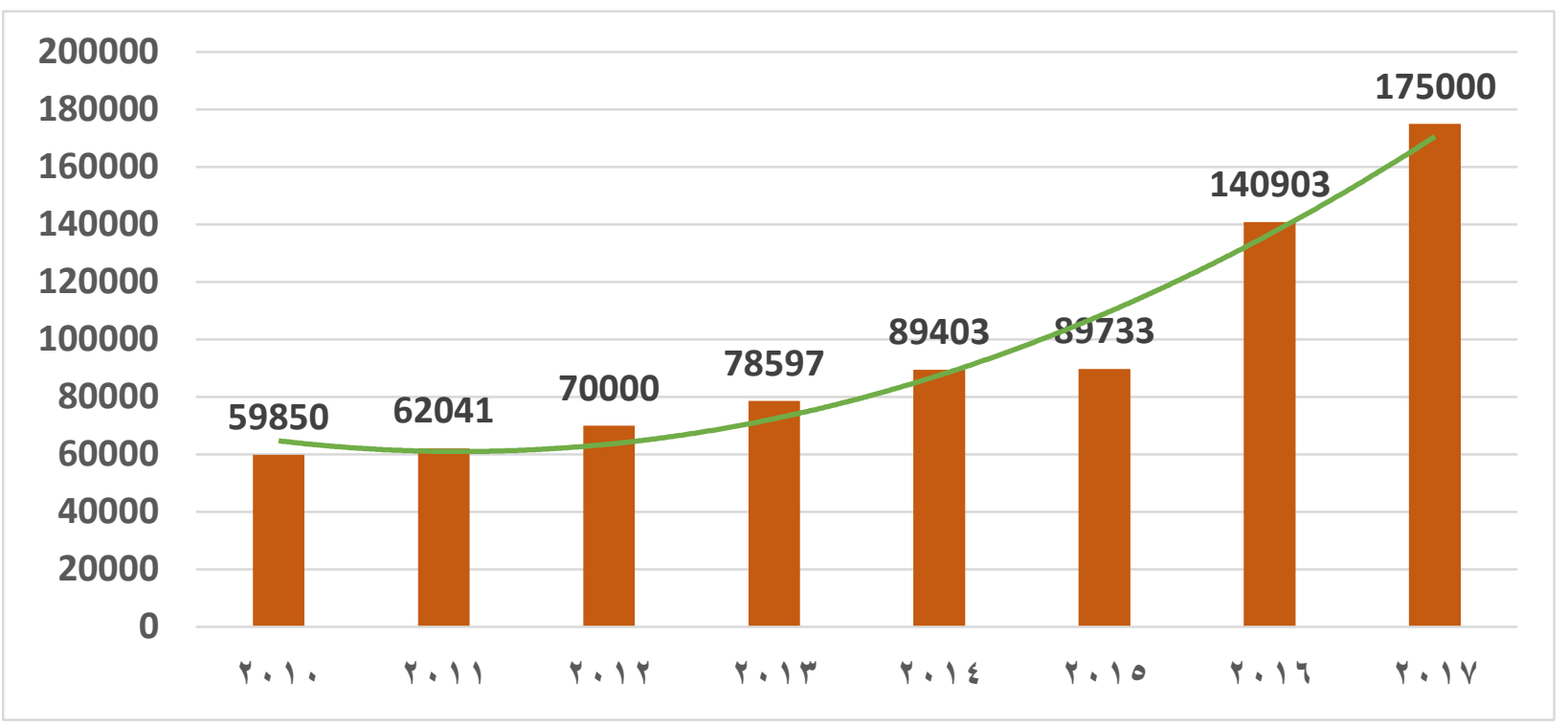

(MAL 2020)

The Afghanistan apple export markets are India, United Arab Emirate, Pakistan, and Meddle East and also Afghanistan produced apple exporting to Europe, Canada, Australia, and central Asia markets

Paktia is the number of apple producer's provinces of the country and is located in South East of Afghanistan. It has 6,432 sq. km, locked in high mountains.

The mountains of Paktia are covered on 146231thousenth hectare land deferent trees and jangles and 39/8 percent of people of this province were busy in the agriculture sector.

Paktia province total 527486 hectares' land in its 316615 range area, 18927 deserts, 285 hectares' gardens, 732 hectares' fruits trees, 4651 drylands rain-fed 70119h underwater irrigated lands. The total products of apple crop 33852 metric tons in 8340 Hectares cultivated in Paktia province. The 2 graphs show his district's level of apple products. 


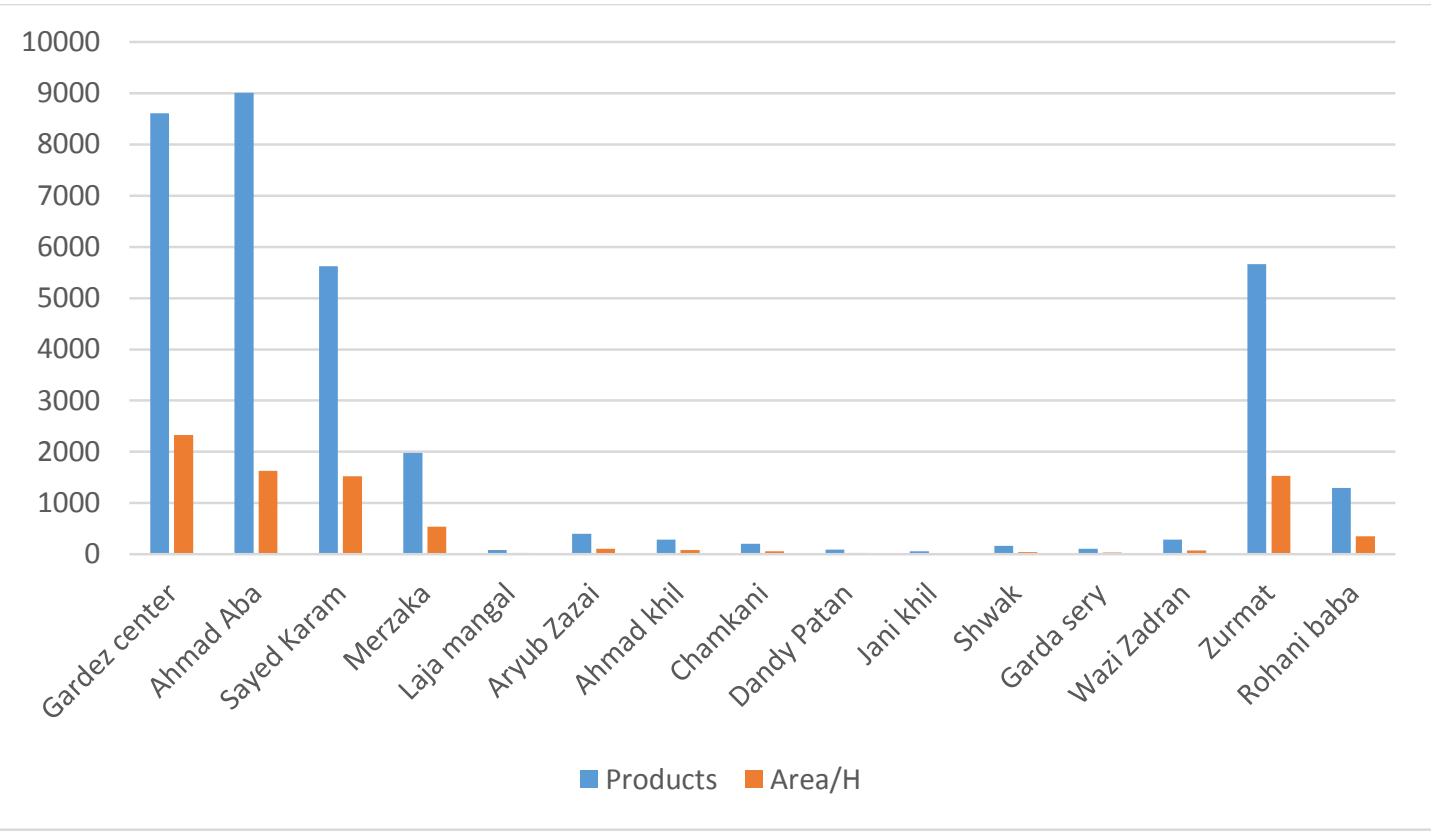

(NSA 2020)

The apple product sale is the main challenge of marketing issue in Afghanistan. Though the ministry of agriculture the end of last year planned sporting programs for the local merchants to sort apple crops to extend usage especially bags (Masood, M.2011). Despite marketing being the main problem of Afghanistan's agricultural sector.

Kumar has believed Marketing is the process including from products crops to receive the consumer hand (Kumar 2015).and also (Muzis 2010) is believed abut marketing operational actions performance for agriculture to spend the best products according to quality and demand of consumer inappropriate time and place for extreme income to consumer supplied is called marketing. The basic function after production of each product receives to consumers' hands, agriculture to developing to prior marketing or increase cities population, farmers have extra responsibility for food security not only for village market but for urban cities.

Marketing effective resources of allocation to create affluence and development economic growth, income betterment from different sections, and keeping stability in supply and demand to assist selling for goods according to world trade suppliants, agricultural development are a necessity for beneficiary units which involved in Bazar service and also toward to exports development.

Unfortunately, many Afghan farmers are not acquainted with marketing, and they cannot sell supplying their products at appropriate Rates to markets. Due to the lack of security and threedecade internal war in Afghanistan. 
There are barriers to many years to invest in infrastructures of agricultural products marketing (Alizai, G.S.A.2020). Many agricultural producers have no access to sufficient new information and market intermediates, especially for rural areas. Low-level literacy between farmers, many incomes of farmers from sale place of agricultural products is less and they are very less expense for products selling market. (Moahid \& Maharjan, 2020).for control in marketing education needs and investment infrastructure. But Unfortunately, afghan commercial agencies in foreign countries for selling agricultural products and finding new markets. Mentioned indicate All problems absence sort, standardized and packing agricultural products. Current packaging methods are faced with losses during the transportation, to keep product against mechanical risks during the long way and the existence wood cartons and plastic packets are very difficult. (Mohammadi, \& Reed. 2020).

Unluckily the insufficient number of cool stores and places for keeping agricultural products incountry in this case also has a heavy cost. Afghanistan has no appropriate transportation system for the transition of agricultural products over long distances. And transit of products from product location to consumption place is other problems of agricultural producers in the country .and agricultural produced much time carrying by tractors, canyons and also by roads and air terminals, and Roads no keeping correctness and also some area impossibly road facility in the result of its products faced to shipment lateness and losses.

(Hashimi, 2020) .The mindfully cases mentioned for Afghanistan agricultural extension to mindfully one of requirement agricultural products marketing and structures needs for changes and necessary for knowledge and information and are increased beneficiaries.

\section{Agricultural Extension and Marketing}

The Extension process is following different objectives of rural development and sustainable agriculture

according to local and regional requirements of different areas.the role of extension in society effect by political conditions, economical, and big politics of societies among the many countries that established this organization for farmers' education. Now the European countries' extension systems in the many different problems of farmers and villagers in different economic and social fields resolution the problems but fowling the main aims exports development agricultural 
products, health, and other. In the $3^{\text {rd }}$ world countries function of extension transition of new initiatives and technology for beneficiaries of farmers and villagers.

The agricultural extension is the bridge of communication between farmers and agricultural organizations for new initiatives, technology, marketing skills for rural area development of the country. The majority of people who are living in rural areas are farmers who have less access to extension services. (Bolton, 2019). The agricultural extension depends on academic methods to the following increase the beneficiary income of farmers (Salman, 2020). Agricultural extension in many countries in the field of increased marketing information, awareness from economic growth, work opportunity, increase empowerment level. Better life quality of rural Areas for families and work for social welfare (Pense, \& Groninger, 2013) .But the extension has a basic role in increasing enjoyment manpower and advancing sales skills. (Sarhadi et al, 2014) but this organization also played the role of organizing Rural societies. (Zwane, \& Kekana, 2014).

The agricultural extension can increase the awareness level of small farmers to assist for agricultural products marketing .fuller believed non-awareness for marketing is the important factor of beating different businesses. (Fuller, 1995). The role of agricultural extension in marketing is communication between markets and farmers but this communication can positive changes in the life of rural Area and effects that are on agricultural products which are rich economy of farmer society and their products are annually getting foreign exchanges to the country(Ali, 2017).therefore the role of extension creation motivation in farmers for increasing the investment in the agricultural sector and creation works opportunities and remarkable economic growth(Selvaratnam, 2016).especially the role of extension in the marketing of agricultural products heretofore conducted a lot of researches.

A study is conducted about the assessment of apple marketing and used the Mark-up module in selling markets meddlers were top from farmers it was a weakness reason of marketing (Rujai and Nasseri 2010). The farmers who have high education are a lot of time spend in marketing activities. (Muqadsi et al2009).

The extension services have a key role in the implementation of programs and projects in Afghanistan and especially extension factors of different technologies agricultural to guide the farmers and motivate them for agriculture development and large participated and performance main role in horticulture and livestock national programs of the country in last five years. 
And Afghanistan horticulture sector has extraordinary growth besides of established new garden by new methods and extension agents were visited and gave technical advised the gardens and farms.

\section{The current research conducted on the below objectives in Paktia province}

1- Assessing the farmers' problems in apple products marketing.

2- Evaluating educational needs of farmers in marketing.

3- Study the role of extensional elements in the knowledge promotion of farmers in apple marketing.

This research is conducted in Paktia province

Paktia is a province of Afghanistan is located South East of Afghanistan. It has $6,432 \mathrm{sq} . \mathrm{km}{ }^{2}$ and $2350 \mathrm{~m}$ highness from Sea level Gardez is the capital of Paktia province. According to the National Statistics and Information Authority (NSIA), Paktia's total population is 601230 Reported in 2019 and 26983 lives were in urban and 563685 people are residents in villages, and the majority of rural area people are busy in agriculture.

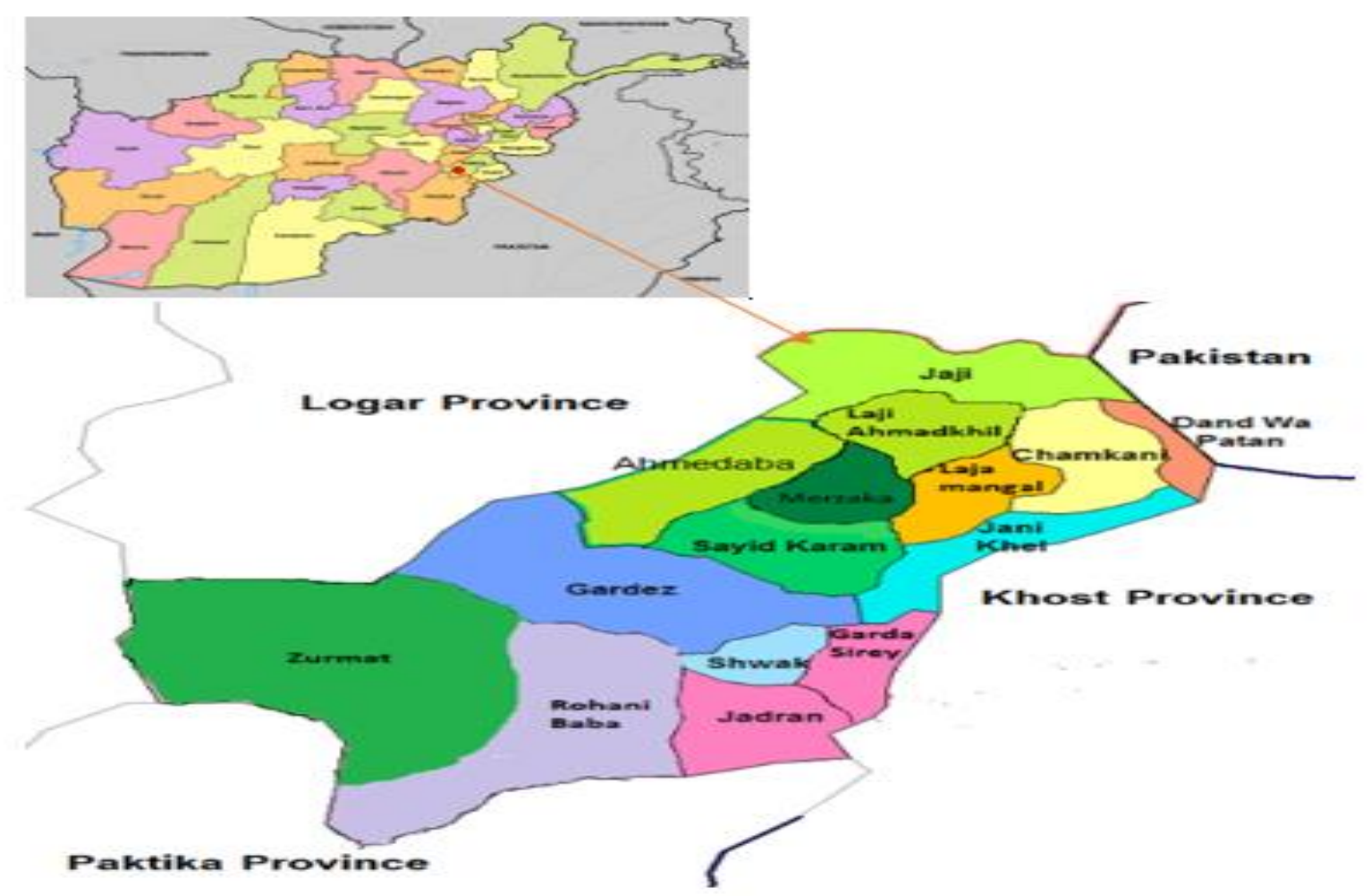

Figure (1) Research area 


\section{Research Model}

Agricultural extension tried to use by different methods and components' to increase the knowledge and awareness of farmers to make good quality and quantity of apple products. Model (1) shows the Research process

\section{Research Model}

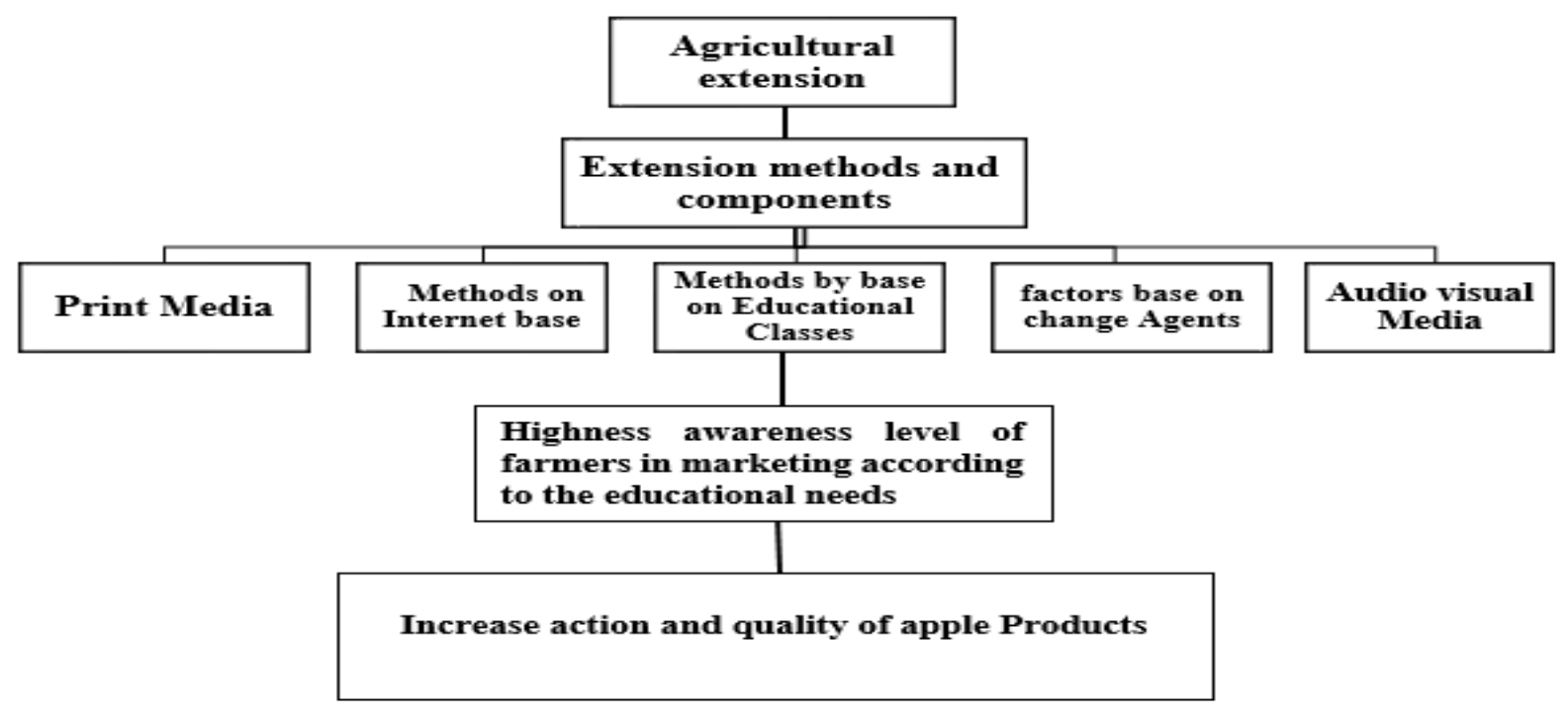

\section{Methods}

The current research is the type of Applied research its performance on survey style decretive methods. The statistical population of the current research is apple farmers in Paktia ProvinceAfghanistan. Who are the number farmers being 14300 farmers according to the information of Paktia agricultural and livestock Department Among the farmer's sample size used from Cochran Formula 200 apple producers selected samples of Research from three districts and selected by Randomize from 66 villages mean for Collection Data is Researcher prepared questioners including 61 questions in different sections, personal, social, extensional and marketing ?but used Likert measurement for respondents' ideas (very agree to agree).in the current research for assignment validity of questioner profits from agricultural extension department lecturer's advice for Reliability technical problems for correctness balance but the social researches researcher are specified the number of validity methods as like Cronbach's alpha methods(Kalantary 2016). And Table (1) shows the balance of Cronbach's alpha performance 
Table (1) Cronbach's alpha for the different sections of the questionnaire

\begin{tabular}{lc}
\hline questionnaire section & Cronbach's alpha(hundredth) \\
\hline producers' problems & $75 / 2$ \\
knowledge and & $81 / 6$ \\
awareness for apple & $78 / 8$ \\
products marketing & \\
measurement use of & \\
extension services &
\end{tabular}

After the data collection is used SPSS software 26 version for experimental and analysis. in this Research chracrastices of population sample by the use of frequency, percent, cumulative percent, Mean, Median, Mode, Std. Deviation, Variance, Skewness, Std. The error of Skewness, Kurtosis, Std. An error of Kurtosis, Minimum, Maximum coefficient are described from statistical methods means to compare and correlation tests and regression used in inferential statistics.

\section{Results and conclusion}

This research is conducted in Paktia province -Afghanistan. And selected sample size from three districts and 66 villages extreme participants in this research from Gardez district and minimum participants from seyd Karam district were selected

Table (2) status age, education, apple farming background, cultivation level, and balance of products in the agricultural year showing in Paktia province.

Table (2) show is the research variable status

\begin{tabular}{lllll}
\hline Variable & minimum & maximum & mean & Std. Deviation \\
\hline Age & 18 & 75 & 45 & $14 / 1$ \\
education & illiterate & $\mathrm{BA}$ & & \\
Apple farming background & 3 & 33 & 12 & $5 / 5$ \\
cultivation level & $0 / 5$ & 7 & $1 / 2$ & 2 \\
balance of products & $0 / 4$ & 42 & $5 / 7$ & $5 / 7$ \\
\hline
\end{tabular}




\section{Apple producer's knowledge of marketing in Paktia province according to the priorities}

In the base of the data table (2) farmers' relevant issues of marketing and all cases ability to lobby and talk with apple customers. (Mean ordinal 3/82 and Std. Deviation 1/185). Awareness is the better time for crop products and ornament to market is the second choice and denotation to apple producers. (Mean ordinal 3/81 and Std. Deviation 1/233).it shows the farmers after many years of apple farming absently to marketing conditions and apple harvest time are differentiated. And the $3^{\text {rd }}$ choice to identify meddlers and customers that are in the marketing discus is to conform to apple producers' population. These are identified as apple producers, exporters, and merchants. (Mean ordinal 3/77 and Std. Deviation 1/175).in three cases are remembered. And farmers are less need for education. Farmers' knowledge priority in different bases in the table. 2

Table (2) the priority base knowledge level and apple producers' educational needs of marketing in Paktia province

\begin{tabular}{|c|c|c|c|c|c|}
\hline Rank & $\begin{array}{l}\text { educational } \\
\text { needs level }\end{array}$ & $\begin{array}{c}\text { Std. } \\
\text { Deviation }\end{array}$ & $\begin{array}{c}\text { knowledge } \\
\text { mean }\end{array}$ & $\mathbf{N}$ & \\
\hline 1 & $2 / 35$ & $1 / 395$ & $2 / 65$ & 199 & $\begin{array}{l}\text { Get acquainted with present-day } \\
\text { techniques of marketing }\end{array}$ \\
\hline 2 & $2 / 15$ & $1 / 305$ & $2 / 85$ & 200 & $\begin{array}{l}\text { You are familiar with the chain } \\
\text { management from production to } \\
\text { consumption of apples }\end{array}$ \\
\hline 3 & $1 / 78$ & $1 / 202$ & $3 / 22$ & 199 & $\begin{array}{l}\text { You are well acquainted with the new } \\
\text { methods of collecting products. }\end{array}$ \\
\hline 4 & $1 / 61$ & $1 / 164$ & $3 / 39$ & 200 & $\begin{array}{l}\text { Familiarize yourself with the correct } \\
\text { methods of product packaging. }\end{array}$ \\
\hline 5 & $1 / 75$ & $1 / 215$ & $3 / 43$ & 198 & $\begin{array}{l}\text { Awareness of market needs and } \\
\text { consumption }\end{array}$ \\
\hline 6 & $1 / 50$ & $1 / 116$ & $3 / 50$ & 200 & $\begin{array}{l}\text { Familiarize yourself with the best } \\
\text { methods to preserve apple products }\end{array}$ \\
\hline 7 & $1 / 48$ & $0 / 988$ & $3 / 52$ & 197 & Apples to market \\
\hline
\end{tabular}


Familiar with proper product delivery

8

$1 / 43$

$1 / 130$

$3 / 75$

$3 / 63$

$9 \quad 1 / 39$

$1 / 102$

$0 / 957$

$3 / 64$

$10 \quad 1 / 36$

$1 / 058$

$3 / 70$

$11 \quad 1 / 30$

$1 / 175$

$3 / 99$

$12 \quad 1 / 23$

$13 \quad 1 / 19$

$1 / 233$

$3 / 81$

$14 \quad 1 / 18$

$1 / 185$

$3 / 82$
197 Familiarize yourself with the

principles of advertising and customer

attraction

198 Familiarize yourself with the methods of selling Apple products

200 You are familiar with determining the price of Apple products

200 You are familiar with the classification of apple products

200 Familiar with apple exporters and traders

200 Be aware of the appropriate time to collect the product and present it to the market

200 Understand ways to communicate, engage, and engage with merchants and buyers

According to the balance of the benefit of apple, producers use extensional methods in Paktia province. Contact with successful farmers and use the knowledge and information is mainly educational methods when farmers are taken profit. (Mean ordinal 3/88 and Std. Deviation 1/062) its second educational methods nearly the first methods and that village are classified. Educational visits model apple gardens when agricultural department preparation for agricultural farmers. (Mean ordinal 3/82 and Std. Deviation 1/174). And ultimately profit from elder's ideas has traditional importance. (Mean ordinal 3/67 and Std. Deviation 1/090). The assessing priority cases showing general extension methods are traditional primary methods. The reason for this phenomenon is primary power full traditional ideas and the second traditional ideas face to face visits. And second, no use and non-acquaintance of the new extension methods in Afghanistan and other educational methods come in priority in the table (3). 
Table (3) according to extensional methods using the balance of apple producers in Paktia province

\begin{tabular}{|c|c|c|c|c|}
\hline rank & Std. Deviation & means & $\mathbf{N}$ & \\
\hline 1 & $1 / 62$ & $3 / 88$ & 199 & $\begin{array}{c}\text { To what extent have you benefited from the } \\
\text { experience and knowledge of successful } \\
\text { gardeners? }\end{array}$ \\
\hline 2 & $1 / 174$ & $3 / 82$ & 198 & $\begin{array}{c}\text { Educational observations from sample apple } \\
\text { orchards }\end{array}$ \\
\hline 3 & $1 / 90$ & $3 / 67$ & 200 & $\begin{array}{c}\text { Benefit from the knowledge and information } \\
\text { of leaders, local trustees, and successful } \\
\text { farmers }\end{array}$ \\
\hline 4 & $1 / 266$ & $3 / 62$ & 200 & Listening to radio agricultural programs. \\
\hline 5 & $1 / 329$ & $3 / 50$ & 199 & $\begin{array}{l}\text { Meetings with extension staff in the office } \\
\text { and on the farm. }\end{array}$ \\
\hline 6 & $1 / 395$ & $3 / 39$ & 200 & $\begin{array}{c}\text { Watching agricultural programs and } \\
\text { programs }\end{array}$ \\
\hline 7 & $1 / 311$ & $3 / 38$ & 198 & Attend meetings and gatherings \\
\hline 8 & $1 / 399$ & $3 / 16$ & 200 & Participation balance in extension classes \\
\hline 9 & $1 / 378$ & $2 / 97$ & 199 & Participate in educational workshops \\
\hline 10 & $1 / 308$ & $2 / 92$ & 200 & $\begin{array}{l}\text { How many contacts do you have with } \\
\text { marketing experts, specialists, and } \\
\text { economists }\end{array}$ \\
\hline 11 & $1 / 324$ & $2 / 72$ & 200 & $\begin{array}{l}\text { Study of Extensive Publications on Apple } \\
\text { Marketing }\end{array}$ \\
\hline 12 & $1 / 133$ & $1 / 83$ & 196 & Level of use of social networks in agriculture \\
\hline 13 & $1 / 111$ & $1 / 68$ & 200 & Internet usage level \\
\hline
\end{tabular}




\section{Data analysis}

\subsection{Hypothesis Tests}

In this research, for assessing the role of extension factors on apple crop marketing is seven hypothesis tests and six of the hypotheses are confirmed.

1- Hypothesis: between the variable balance of awareness apple gardeners from knowledge of marketing and use the variable balance of audiovisual media it has a meaningful relationship. It's also showing in table (4) between two variables (coefficient quantity equal Sig =0/499 and 0/000) and it has a positive meaning level relationship .0/01.

2- Hypothesis: between apple farmer's educational needs and balance of use print methods are meaningful relationship. Table (4) is showing (coefficient quantity equal Sig =0/254 and 0/000) and it has a positive meaning level relationship .0/01.

3- Hypothesis: apple farmers' educational needs and participation in educational classes are meaningful relationships. It Used for attention to variables types of research spearman correlation coefficient according to the table (4) is showing between these two variables (coefficient quantity equal Sig $=0 / 513$ and 0/000) and it has a positive meaning level relationship .0/01.

5- Hypothesis: between apple farmer's educational needs and visit Agents of Change are meaningful relationship It Used for attention to variables types of research spearman correlation coefficient According to the table (4) is showing between these two variables (coefficient quantity equal Sig $=0 / 643$ and $0 / 000$ ) and it has a positive meaning level relationship .0/01.

6- Hypothesis: between apple farmer's educational needs and products performance balance are meaningful relationship It Used for attention to variables types of research spearman correlation coefficient According to the table (4) is showing between these two variables (coefficient quantity equal $\mathrm{Sig}=0 / 030$ 0/411 and 0/000) and it has a positive meaning level relationship $.0 / 01$.

Table (4) the hypotheses test correlation coefficient and meaningful level

\begin{tabular}{ccccccc}
\hline $\begin{array}{c}\text { independent } \\
\text { variable }\end{array}$ & Scale & $\begin{array}{c}\text { dependent } \\
\text { variable }\end{array}$ & $\begin{array}{c}\text { Scale } \\
\text { measurement }\end{array}$ & $\begin{array}{c}\text { type of } \\
\text { correlation }\end{array}$ & $\begin{array}{c}\text { Quantity } \\
\text { of }\end{array}$ & $\begin{array}{c}\text { Meaning } \\
\text { level }\end{array}$ \\
& & & & coefficient & correlation & \\
& & & & & coefficient &
\end{tabular}


Academic Journal of Research and Scientific Publishing | Vol 3 | Issue 34

Publication Date: 5-2-2022ＩSSN: 2706-6495

\begin{tabular}{|c|c|c|c|c|c|c|}
\hline $\begin{array}{l}\text { Use } \\
\text { Audiovisual } \\
\text { media }\end{array}$ & Ordinal & $\begin{array}{l}\text { Knowledge } \\
\text { and } \\
\text { awareness of } \\
\text { marketing }\end{array}$ & Ordinal & spearman & $0 / 499 * *$ & $0 / 000$ \\
\hline $\begin{array}{l}\text { Use print } \\
\text { media }\end{array}$ & Ordinal & $\begin{array}{l}\text { Knowledge } \\
\text { and } \\
\text { awareness of } \\
\text { marketing }\end{array}$ & Ordinal & spearman & $0 / 254 * *$ & $0 / 000$ \\
\hline $\begin{array}{l}\text { Used social } \\
\text { networks }\end{array}$ & Ordinal & $\begin{array}{l}\text { Knowledge } \\
\text { and } \\
\text { awareness of } \\
\text { marketing }\end{array}$ & Ordinal & spearman & $0 / 067 * *$ & $0 / 345$ \\
\hline $\begin{array}{l}\text { Participation } \\
\text { in } \\
\text { educational } \\
\text { classes }\end{array}$ & Ordinal & $\begin{array}{l}\text { Knowledge } \\
\text { and } \\
\text { awareness of } \\
\text { marketing }\end{array}$ & Ordinal & spearman & $0 / 513 * *$ & $0 / 000$ \\
\hline $\begin{array}{l}\text { Visit with } \\
\text { agents of } \\
\text { change }\end{array}$ & Ordinal & $\begin{array}{l}\text { Knowledge } \\
\text { and } \\
\text { awareness of } \\
\text { marketing }\end{array}$ & Ordinal & spearman & $0 / 634 * *$ & $0 / 000$ \\
\hline $\begin{array}{l}\text { Products } \\
\text { operation }\end{array}$ & Ordinal & $\begin{array}{l}\text { Knowledge } \\
\text { and } \\
\text { awareness of } \\
\text { marketing }\end{array}$ & Ordinal & spearman & $0 / 411 * *$ & $0 / \mathbf{0 3 0}$ \\
\hline
\end{tabular}

$*$ meaning level $0 / 05$
$* *$ meaning level $0 / 01$

5.2. Hypothesis:

according to the districts of Paktia province awareness mean of apple producers between meaningful differences. For the measurement of farmer's education level abut marketing in different districts of Paktia province used analysis F test variance. Its result is shown in table (5) 
and also observation in one percent level quantity of test its meaning between different districts assessing cases according to knowledge balance and its results are educational need has meaningful different.

Table (5) assessing 3 districts cases account analysis variance different knowledge level

\begin{tabular}{cccccc}
\hline & $\begin{array}{c}\text { Sum of } \\
\text { squares }\end{array}$ & df & $\begin{array}{c}\text { Mean of } \\
\text { squares }\end{array}$ & $\begin{array}{c}\text { Amount of } \\
\text { F }\end{array}$ & $\begin{array}{c}\text { Level of } \\
\text { meaningful }\end{array}$ \\
\hline $\begin{array}{c}\text { Between } \\
\text { groups }\end{array}$ & $1964 / 677$ & 2 & $982 / 338$ & $14 / 566$ & $\mathbf{0 / 0 0 0}$ \\
$\begin{array}{c}\text { between } \\
\text { groups }\end{array}$ & $13286 / 103$ & 197 & $67 / 6442$ & & \\
sum & $1525 / 780$ & 199 & & & \\
\hline
\end{tabular}

For assessing the differentiation of districts and classification is used shifa test.it results showing in the Table (6). Also the districts 1 and 2 have one level but the level of awareness of Ahmada districts is the first level less meaningful than two other districts.

Table (6) show the result of the Shifa test assessing different educational level of districts

\begin{tabular}{cccc}
\hline District & no of sample & Group 1 & Group 2 \\
\hline Ahmad aba & 65 & $44 / 2000$ & \\
\hline Gardez & 75 & & $50 / 4800$ \\
\hline Seyd karam & 60 & & $51 / 3167$
\end{tabular}

\section{Evaluation of the farmers' knowledge balance of effective factors on apple crop marketing in Paktia}

What are the totally methods and extensional factors that affect farmers' awareness' level? The answer to this question is used from multi variables linear regression and step-wise methods. In the table, 7 to 9 steps work performance and specified results of the activity. 
Academic Journal of Research and Scientific Publishing | Vol 3 | Issue 34

Publication Date: 5-2-2022ＩSSN: 2706-6495

Also, noted variables are the entire level of equation and Result is created three models its results showing farmers knowledge level abut marketing.0/440 percent relevant with agricultural extension and Hangover is relevant to other factors.

Table (7) examine meaningful entire variables to the equation

\begin{tabular}{ccccc}
\hline model & $\mathbf{R}$ & ${ }^{\mathbf{2}} \mathbf{R}$ & R tempered & error \\
\hline 1 & $0 / 634$ & $0 / 402$ & $0 / 399$ & $6 / 78617$ \\
2 & $0 / 659$ & $0 / 435$ & $0 / 429$ & $6 / 61518$ \\
3 & $0 / 670$ & $0 / 448$ & $0 / 440$ & $6 / 55204$ \\
\hline
\end{tabular}

Table (8) ANOVA

\begin{tabular}{cccccc}
\hline model & $\begin{array}{c}\text { Sum of } \\
\text { squares }\end{array}$ & df & $\begin{array}{c}\text { Mean of } \\
\text { squares }\end{array}$ & F & Sig \\
\hline Regression & $6132 / 475$ & 1 & $6132 / 475$ & $133 / 146$ & b.0/000 \\
\hline Hangover & $9118 / 305$ & 78 & $46 / 052$ & & \\
\hline Total & $15250 / 780$ & 79 & & & \\
\hline Regression & $6629 / 930$ & 2 & $3314 / 965$ & $75 / 752$ & $\mathbf{0} / \mathbf{0 0 0}$ \\
\hline Hangover & $8620 / 850$ & 77 & $43 / 761$ & & \\
\hline Total & $15250 / 780$ & 79 & & & $\mathbf{0} / \mathbf{0 0 0}$ \\
\hline Regression & $3826 / 656$ & 3 & $2788 / 885$ & $53 / 085$ & \\
\hline Hangover & $8414 / 124$ & 76 & $42 / 929$ & & \\
\hline Total & $15250 / 780$ & 79 & & & \\
\hline
\end{tabular}

Table (9) entire steps of variables to the equation

\begin{tabular}{lccccc}
\hline \multicolumn{1}{c}{ model } & b & $\begin{array}{c}\text { Std. } \\
\text { Deviation }\end{array}$ & $\boldsymbol{\beta}$ & $\mathbf{t}$ & $\begin{array}{c}\text { Meaning } \\
\text { level }\end{array}$ \\
\hline Coefficient fixed 1 & $24 / 149$ & $2 / 180$ & & $11 / 077$ & $0 / 000$ \\
\hline Visit with agent of change & $1 / 759$ & $0 / 152$ & $0 / 634$ & $11 / 540$ & $000 / 0$ \\
\hline
\end{tabular}


Academic Journal of Research and Scientific Publishing | Vol 3 | Issue 34

Publication Date: 5-2-2022 ISSN: 2706-6495

\begin{tabular}{lccccc}
\hline Coefficient fixed 2 & $22 / 786$ & $2 / 163$ & & $10 / 533$ & $000 / 0$ \\
\hline Visit with agent of change & $1 / 431$ & $0 / 178$ & $0 / 516$ & $8 / 049$ & $000 / 0$ \\
\hline Audio visual media & $0 / 849$ & $0 / 252$ & $0 / 516$ & $3 / 372$ & $0 / 001$ \\
\hline Coefficient fixed 3 & 21.931 & $2 / 178$ & & $10 / 070$ & $000 / 0$ \\
\hline Visit with agent of change & $1 / 230$ & $0 / 198$ & $0 / 443$ & $6 / 201$ & $000 / 0$ \\
\hline Audio visual media & $0 / 702$ & $0 / 258$ & $0 / 179$ & $2 / 717$ & $0 / 007$ \\
\hline $\begin{array}{l}\text { Participate in educational } \\
\text { classes }\end{array}$ & $0 / 351$ & $0 / 160$ & $0 / 152$ & $2 / 194$ & $0 / 029$
\end{tabular}

the mentioned base of regression table shows the profit from extension officers or agents of change of agriculture, extensions helpers, and all humanity relevant factors has effects on the agricultural sector in increasing awareness of farmers in apple marketing. After this factor uses Radio and television and also conducted educational classes. Are affected on farmers' awareness. it's can mapping in the below equation

$\mathrm{Y}=21 / 931+1 / 230 \mathrm{x}_{1}+0 / 702 \mathrm{x}_{2}+0 / 351 \mathrm{x}_{3}$

In this equation

$\mathrm{X} 1=$ equal the balance of farmer visits with agents of changes.

$\mathrm{X} 2=$ equal the balance of use Audiovisual media

$\mathrm{X} 3$ equals the balance of Participation in educational classes.

\section{Conclusion and suggestions}

Agricultural products marketing is a Requirements of Agricultural and Rural Development in Afghanistan. And un familiarizes as concept and process of marketing, less profit beneficiary balance from selling product from meddlers in this alliance extension as presented different educations by the use on various media knowledge profit beneficiary are increasing the field of marketing .and mentioned to the results of research and suggestion below cases.

1- Agriculture irrigation and livestock ministry for better horticulture sector must be employment high power full and professional agents. 
2- Afghanistan Audiovisual media like radio and television conducted round tables and discussion meetings for experts and better sample apple orchards invite to programs and broadcasting educational films.

3- The government for education and better awareness use social channels and networks like Facebook, telegram, and WhatsApp.

4- Paktia Agriculture irrigation and livestock department. For the control of extreme fluctuations in marketing performance basic activates to guaranteed agricultural product costs.

5- The government should be the performance to industry change and fabrication apple and investment for keeping products

6- Agriculture irrigation and livestock ministry should be building a standard and equipped cool store for keeping apple products in Paktia.

7- Agriculture irrigation and livestock ministry should be traditional methods of keeping products to change modern methods.

\section{References}

- Peroshabani,m (2010)Iranian farmers semenar and world markets,magazine jahad,issue191.

- Rjai,E,nasseriy (2010)assessment apple marketing in Oromai district by used Mark-up modle.quantitive researchs in management azad abher payeezr. 2010.issue 2.

- Rosta,A,wanosh,D and ibrahimi,A. (1996).tehran marketing management:study and liberal arts books preparation organization universities.(side).

- Shaban ali fami,H (2009) book principle of agricultural extension and education payam noor press.

- Ana bastani,A,WM. Toolaby najad (2019). Assessment of agricultural products marketing of barrers and challenges the central part Pal dukhtaran district are used analysis channel phase.magazine of space geoghrspycal preparedness, sentific quarterly- studious of Gulistan university.2019.

- the role of extension in kiwi marketing in Mazandaran (2013) Muqadasi,R, and Azad Tankabin districts.agricultural and extension researches2 tdy in Chaloosh andprovince(case su .(winter 2009) 
- D.P., Bhavani, R.V., and Swaminathan, M.S. (2014). A Farming System Model to everage Agriculture for Nutritional Outcomes, Agricultural Research, 3(3): 193-203

- Fuller, P.B. (1994). Assessing marketing in small and medium-sized enterprises. European Journal of Marketing, 28 (12): 34-49.

- Sheepher, G.S. and G.A Futrell. (1996). Marketing Farm Products: Economic Analysis. Iowa State Univ. Press, at: Http://ecsocman.edu.ru /db/msg/119211.htm

- Ali, A. (2017). Actors and Stakeholders in Agricultural Extension Practice: The Role of Extension and Advisory System (Eas) In Agricultural Marketing In Nigeria. Fudma Jaat, 2(2), 94-106.

- Alizai, G. S. A. (2020). UNDERSTANDING LEGAL BARRIERS TO FOREIGN INVESTMENT IN AFGHANISTAN: A CASE STUDY IN HERAT INDUSTRIAL ZONE. International Journal of Research-GRANTHAALAYAH, 8(12), 80-102.

- Bolton, L. (2019). Agriculture in Afghanistan-economic sustainability and sub-sector viability.

- Hashimi, S. M., Nawi, N. M., Man, N., \& Mohammad, K. (2020) Marketing of Apricot Supplied to the Market in Kandahar, Afghanistan.

- Masood, M. (2011). An assessment of apple post-harvest losses, the case of nerkh district, Afghanistan. Van Hall Larenstein University of Applied Sciences, 10

- Moahid, M., \& Maharjan, K. L. (2020). The Role of Credit Obtained from Input Suppliers in Farm Investment in Afghanistan. Journal of contemporary India studies: space and society, Hiroshima University, (10), 1-16.

- Mohammadi, H., \& Reed, M. (2020). Saffron marketing: challenges and opportunities. In Saffron (pp. 357-365). Woodhead Publishing.

- National statistics and information authority. (NSAIA). (2018). Afghanistan Statistical Yearbook. Issue No: 39, Jun 2018.

- Pense, S. L., \& Groninger, J. W. (2013). Assessing extension education efforts in Afghanistan through the eyes of US agricultural support personnel. Online Journal for Workforce Education and Development, 6(1), 4.

- Salman, M. A. (2020). The Role of Agricultural Extension against the Challenges that Facing Farmers within their Agricultural Activities. Plant Archives, 20(2), 2996-3001. 
- Sarhadi, W. A., Fahim, S. A., \& Tangutan, K. (2014). Sustainable agricultural development in Afghanistan. Journal of Developments in Sustainable Agriculture, 9(1), 41-46.

- Selvaratnam, R. G. (2016). Afghanistan-Additional Financing to National Horticultural and Livestock Project: environmental and social management framework (No. SFG2149, pp. 1-1). The World Bank.

- World Bank. (2017). Afghanistan Development Update, May 2017. Washington, DC. (C) World Bank. https://openknowledge.worldbank.org/handle/10986/27550 License: CC BY 3.0 IGO.

- Zanello, G., Shankar, B., \& Poole, N. (2019). Buy or make? Agricultural production diversity, markets and dietary diversity in Afghanistan. Food Policy, 87, 101731.

- Zwane, E., \& Kekana, E. (2014). The role of extension in agricultural cooperative development in Limpopo. International Journal of Agricultural Extension, 2(2), 147-152.

- Muradi, A. J., \& Boz, I. (2018). The contribution of agriculture sector in the economy of Afghanistan. International Journal of Scientific Research and Management, 6(10).

- Paktia Agriculture- Department (2020). Afghanistan.

- Paktia province. Report.issue no: 1 December 15.2019. ansary square Kabul.afghnistan.

- Paktia. Provincial. Report (2018). Paktia province annually report. Issue no: 6 noember anssary square Kabul.afghanistan..

- Mzyece, A. (2010). Factors influencing cowpea producers' choice of marketing channels in ZAMBIA. Available at: http://valuechains.k-state.edu/_Agness\%20Mzyece

Copyright (C) 2022 Sherpaw Ahmadi, Heshmatollah Saadi, Muhsenullah Irfan, Raza Movahedi, AJRSP. This is an Open-Access Article Distributed under the Terms of the Creative Commons Attribution License (CC BY NC)

Doi: doi.org/10.52132/Ajrsp.e.2022.34.4 